\title{
New data on the occurrence and macroptery of Eumodicogryllus bordigalensis (LATREILLE, 1804) (Orthoptera: Gryllidae) in Poland and in other parts of the species range
}

\author{
ANNA LIANA*, WiOLETTA WAWER \\ Museum and Institute of Zoology PAS, Wilcza 64, 00-679 Warszawa, Poland
}

\begin{abstract}
A dozen specimens of Eumodicogryllus bordigalensis were found in three localities in Poland as well more than thirty foreign specimens of the species collected in southern Europe, the Caucasus and Mongolia. They are deposited in the collection of the Museum of Zoology PAS. The adult specimens were studied in detail and measured. The indigenous specimens and the majority of the foreign ones proved to be macropterous. The problems of wing polymorphism and the possibilities of migration are discussed.
\end{abstract}

KEY WORDS: southern cricket, south-eastern regions of Poland, macropterous form, migration.

\section{INTRODUCTION}

Many observations of thermophilic species extending their ranges from south to north are usually explained by climate change. Less attention is paid to the increasing role of humans in the displacement of species (intended or not) and their own tendencies and opportunities for expansion. The case of Eumodicogryllus bordigalensis (LATREILLE, 1804) seems to be an interesting example of how all these threads are intertwined.

The southern cricket was first noted in Poland in the $1950 \mathrm{~s}^{1}$ but primarily it was erroneously mentioned as Acheta desertus (PALLAS, 1771) by KostrowICKI (1953). Under the name Tartarogryllus burdigalensis (LATREILLE, 1804) it was listed in a monograph of indigenous Gryllidae (LIANA 1975) and later in the Catalogue of Polish Orthoptera

* Corresponding author: aliana @ miiz.waw.pl

${ }^{1}$ In the MIZ PAS collection there is one specimen collected by S. TOLL near Zaleszczyki in 1935. At that time this locality was in Poland; now it is in Ukraine. 
(BAZYLUK \& LIANA 2000). The recatch of the species took place in Poland only in 2001 (a series of specimens) and in 2012 (one specimen), both times in the south-eastern regions of the country. No information about either these specimens or the foreign specimens of Eumodicogryllus bordigalensis in our collection has yet been published.

The range of E. bordigalensis covers mainly the Mediterranean countries of Europe and North Africa, where it is quite common (CHOPARD 1943, 1951, VOISIN 2003, HARZ 1969, HerRera 1982, Olmo-VIDAl 2006, MASSA et al. 2012, WILLEMSE 1984, ThORENS \& NADIG 1997). The species is also known from Asia Minor, the Caucasus, Central Asia and Mongolia. It is widely dispersed in central Europe, where most of its records are recent ones. It was discovered not long ago in southern Germany (near Karlsruhe) (ELST \& SCHUlte 1995, MAAS et al. 2002), and in northern Switzerland (near Basel) (BIRRER \& CORAY 2000) and in Lower Austria (BERG \& ZUNA-KRATKY 1997). It is considered to be very rare in southern Slovakia and the Czech Republic (CHLÁDEK 1973, HolušA et al. 2007). STOROZHENKO \& GOROCHOV (1992) recorded this species in Transcarpathia (Ukraine). BouWman (2010) found it at Ede (the Netherlands) - probably the most northern locality in Europe.

The southern cricket, described by LATREILLE (1804) in the genus Gryllus LinNAEUS, 1758, was later placed in several other genera (Acheta FABRICIUS, 1775, Tartarogryllus TARBINSKY, 1940, Modicogryllus CHOPARD, 1961), before finally being located in a new genus Eumodicogryllus by GOROCHOV (1986). Due to the great variability of such features as the colouration and patterns of the head and wing length, the southern cricket has been described under various species names. More than a dozen of its synonymous names are currently known, some of them are used as sub-specific or form names. BRUNNER V. WATTENWYL (1882) had already noticed that specimens of this species, characterized by different wing lengths, often appeared together in the same locality. CHOPARD $(1943,1951)$ named forms differing in wing length: burdigalensis (shortened second pair of wings), cerysyi (tegmina longer than abdomen, second wings "caudate" and about twice as long as the tegmina) and geminus (both pairs of wings shortened). Some problems related to the names of genus and species were clarified by CORAY \& LEHMANN (1998) based on a decision of the International Commission of Zoological Nomenclature (Opinion ICZN, Bull. Zool. Nom. 1999).

The aim of this study was to extend knowledge of the current range of E. bordigalensis and to pay attention to the possible role of macroptery (wing polymorphism) in observed expansion of species to the North. 


\section{MATERIALS AND METHODS}

The data referring to specimens of E. bordigalensis in the collection of the Museum and Institute of Zoology, Polish Academy of Sciences (MIZ PAS), Warsaw, are listed below.

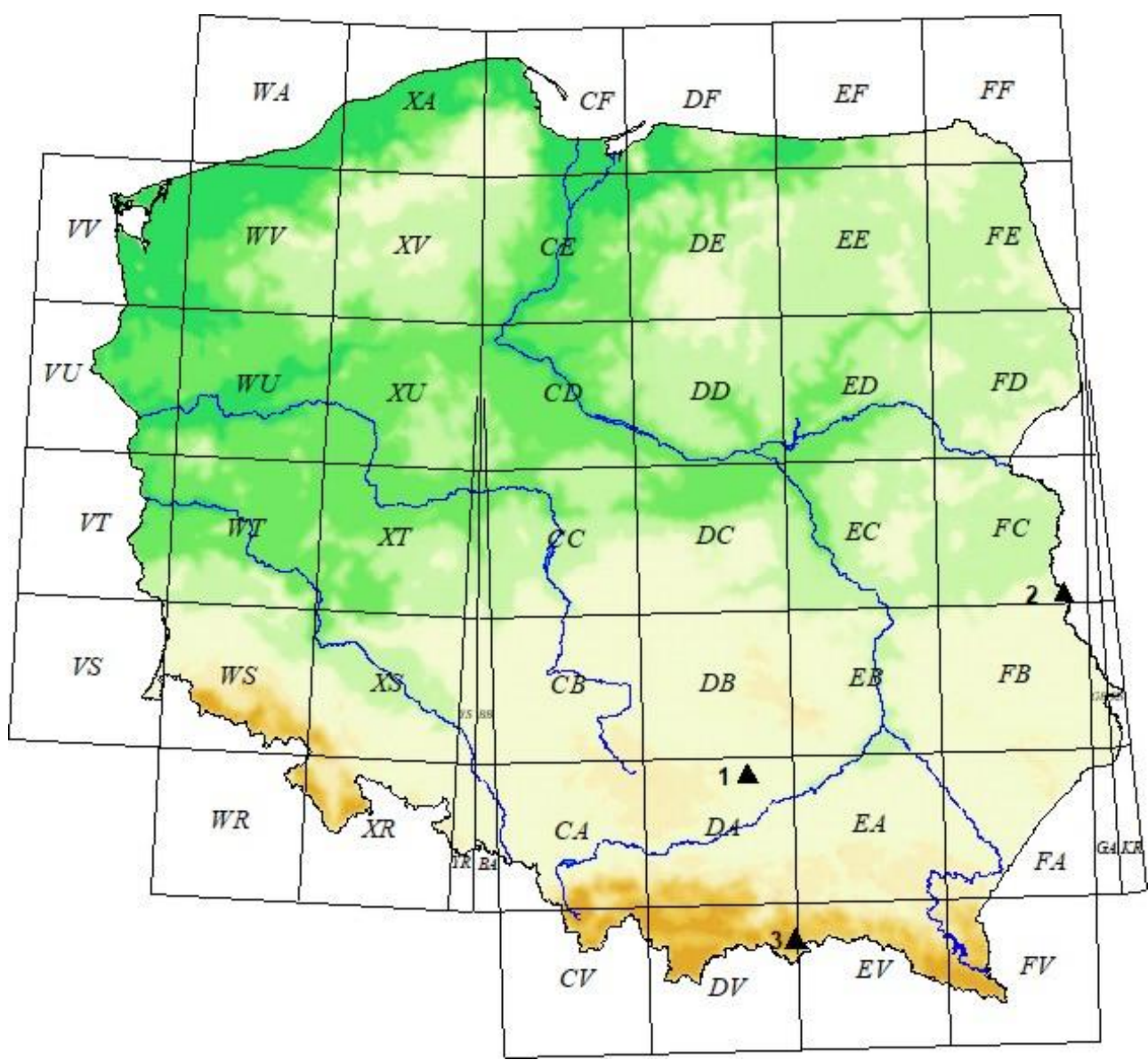

Fig. 1. Localities of Eumodicogryllus bordigalensis in Poland: 1 - Krzyżanowice; 2 - Sobibór; 3 - Krynica.

Polish localities (Fig. 1): 1) Małopolska Upland, Krzyżanowice, xerothermic hill, 13.07.1952, ad lucem, 1§̂, Entomological Team of PZM leg., cited by LIANA (1975) as Tartarogryllus burdigalensis; 2) Lublin Polesie, Łęczna Włodawa Lake District, Sobibór ad Włodawa, farm buildings, 15-25.07.2001, ad lucem, 1ठ, 9우, A. MALKIEWICZ and M. 
WANAT leg., 15.07.2001, ad lucem, 10, 4우, M. WANAT leg.; 3) Beskid Sądecki Mts., Krynica Kopciowa, a forester's orchard, ad lucem (mercury vapour lamp), 30.08.2012, 1q, M. ŁUSZCZAK leg. All specimens were macropterous.

Foreign localities: 1) Ukraine, Wołoczków ad Zaleszczyki, 27.06.1935, 1ㅇ, S.T. ToLL leg.; 2) Romania, Bucureşti, 11.08.1958, 10̂, W. BAZYLuK leg.; 3) Bulgaria, Ropotamo, 08.06.1959, 2우, brachypterous, R. BAŃKOWSKA leg.; 4) Yugoslavia (now Northern Macedonia), Ohrid, 18.11.1960, 9 juv., W. BAZYLuK leg.; 5) Mongolia, Sajn Sand, 10.05.1962, 1 juv., B. PISARSKI leg.; 6) Mongolia, Zum Bajan, 21.07.1963, 2우, B. BURAKOWSKI and H. SZELEGIEWICZ leg.; 7) Georgia, Suchumi, 12.11.1963, 2 juv., R. BAŃKOWSKA leg.; 8) Georgia, Sochi, 07.12.1963, 1 juv., R. BAŃKOwSKA leg.; 9) Bulgaria, Rhodope Mts., Podkova and Momčilgrad ad Kirdžali, 17-18.10.1964, 3 juv., R. BIELAwSKI leg.; 10) Bulgaria, Primorsko, 03.08.1964, 1 juv., R. BAŃKOWSKA leg.; 11) Bulgaria, Zlatni Pjasici ad Varna, 31.08.1964, 10, 2우, S. ADAMCZEWSKI leg.; 12) Romania, Danube Delta, Caraorman, 23-25.08.1965, 1ㅇ, A. LIANA leg.; 13) Spain, Coto Doňana, Huelva

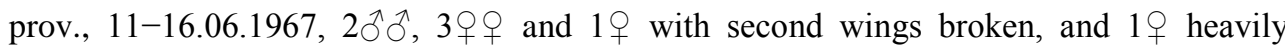
damaged, B. MALKIN leg.; 14) Bulgaria, Damianica ad Sandanski, 3-4.09.1969, $1 \overbrace{}^{\circledR}$ brachypterous, A. LIANA leg.

All specimens were identified or their determination confirmed by Anna LiANA. The 17 adult Polish specimens of E. bordigalensis and the 18 foreign specimens were examined and measured using a stereoscopic microscope with a special ocular.

\section{RESULTS}

The two new indigenous records of E. bordigalensis have confirmed the presence of the species in the Polish fauna, even if it is only temporary. All the southern crickets in Poland were long-winged and caught when they were attracted to light; none have yet been observed living free in the natural habitat. It is striking that nearly all the foreign adult specimens were macropterous, except for two females from Ropotamo, one male from Damianica and one female from Coto Doňana with its second wings broken. A few of the foreign specimens were collected in their natural habitats by sweeping (e.g. the macropterous female in Caraorman and the brachypterous male in Damianica). The two macropterous females from Zum Bajan (Mongolia) were probably attracted to a hotel light. We do not know exactly how most of the foreign specimens were collected, as the relevant information is not given on the labels. We suppose that they were occasionally captured with standard methods used for different insect groups by various specialists (sweeping, visual observation, searching under stones). The same methods used during many years of investigations in different regions of Poland (including Krzyżanowice and its 
neighbourhood, Sobibór and the Łęczna-Włodawa Lake District, Krynica and the Beskid Sądecki Mts.) did not yield any new records of this species. Among the Gryllidae only Gryllus campestris LINNAEUS, 1758 and Modicogryllus frontalis (FIEBER, 1844) (in Krzyżanowice) were collected in this way (Tables 1,2).

Table 1. Dimensions in mm (17 specimens from Poland).

\begin{tabular}{|c|c|c|c|c|}
\hline Location & Body length & $\begin{array}{c}\text { Tegmen } \\
\text { length }\end{array}$ & $\begin{array}{l}\text { Wings II } \\
\text { length }\end{array}$ & $\begin{array}{c}\text { Ovipositor } \\
\text { length }\end{array}$ \\
\hline Sobibór 13 우우 & $11.0-14.0$ & $7.5-9.0$ & $17.0-19.0$ & $7.2-9.0$ \\
\hline Sobibór $2 \widehat{ } \sigma^{\lambda}$ & $12.0-13.0$ & 7.8 & 17.0 & - \\
\hline Krynica $\bigcirc$ & 12.5 & 7.8 & 17.0 & 7.9 \\
\hline Krzyżanowice $q$ & 13.0 & 8.0 & 17.0 & 7.7 \\
\hline
\end{tabular}

Table 2. Dimensions in mm (18 adult specimens from foreign countries).

\begin{tabular}{|c|c|c|c|c|}
\hline $\begin{array}{l}\text { Location } \\
\text { (country) }\end{array}$ & Body length & $\begin{array}{c}\text { Tegmen } \\
\text { length }\end{array}$ & $\begin{array}{c}\text { Wings II } \\
\text { length }\end{array}$ & $\begin{array}{c}\text { Ovipositor } \\
\text { length }\end{array}$ \\
\hline Ukraine $q$ & 16.0 & 8.5 & 17.5 & 7.5 \\
\hline Spain $2 \sigma^{\lambda} \sigma^{\lambda}$ & $13.0-13.5$ & $7.8-8.0$ & $16.5-17.3$ & - \\
\hline Spain 5 우 & $11.0-13.5$ & $8.0-10.0$ & $16.5-17.5$ & $7.0-8.0$ \\
\hline Bulgaria $2 \hat{\sigma} \widehat{0}$ & $12.8-13.0$ & $7.0-7.5$ & 16.5 & - \\
\hline Bulgaria $4 ㅇ ㅜ$ & $11.5-13.5$ & $6.2-8.5$ & 17.5 & $6.9-8.5$ \\
\hline Romania $\hat{\sigma}$ & 14.0 & 7.0 & 17.6 & - \\
\hline Romania ㅇ & 13.5 & damaged & 16.8 & 8.0 \\
\hline Mongolia $2 ㅇ+9$ & $12.5-14.0$ & $7.3-7.5$ & $17.0-17.5$ & $7.2-8.6$ \\
\hline
\end{tabular}

The dimensions of the adult specimens studied here (both native and foreign) are close to the limits given by other authors (HARZ 1969, MASSA et al. 2012). Only the length of the female body from Ukraine $(16 \mathrm{~mm})$ goes far from the known data, except for CORAY (2002), who states the limits for females as being 14-18 mm ("Alkoholmaterial"). Moreover, the length of the tegmina does not differ according to the data given by other authors. Except four specimens that probably shed second-pair-wings, all the specimens are characterized by very long wings, more than twice as long as the tegmina. Their lengths correspond with the data of CORAY (2002). 


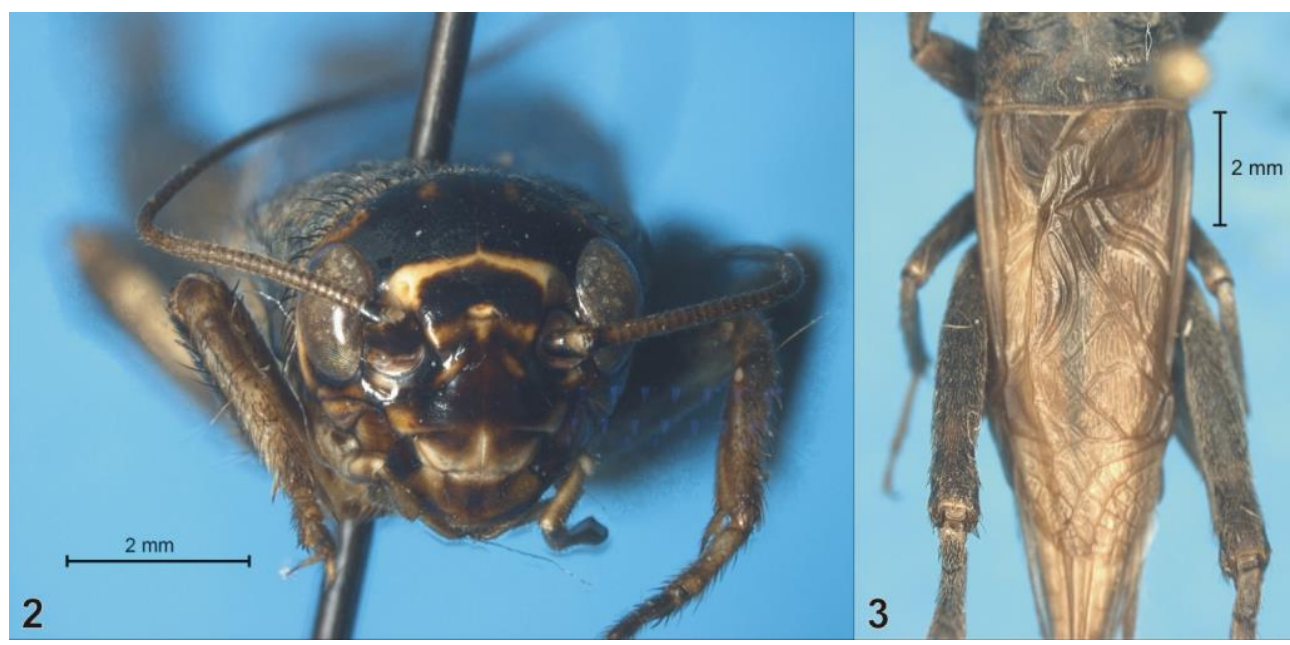

Figs 2-3. Eumodicogryllus bordigalensis: 2 - frontal part of head (female, Sobibór); 3 - tegmina of male (Sobibór).

The acute angle formed by the front-clypeal suture near the median ocellus was present in all the adult and juvenile specimens examined (Fig. 2). This morphological feature enables the correct identification of E. bordigalensis, despite the great variability of the head colouration and the distribution of the black and yellow pattern on it. The ground colour is generally dark, most often dark brown or chestnut, seldom black. The pattern is formed by a yellow band of varying width or a yellow patch between the antennae, and a band or thin line between the eyes. On the occiput the pattern is formed by 4-6 more or less visible longitudinal patches. In addition, some specimens have yellow spots on the labrum, the genae and the occiput near the eyes. In general, the darker the ground colour, the less pronounced the yellow pattern.

The pronotum is dark brown with clearer marbled patterns on a disc and light patches on the fore parts of the lateral lobes, the edges are thickened with black bristles. The abdomen is dark brown or nearly black but cleared by a cover with a thick, brightly coloured pubescence. The tegmina are light-brown or yellowish-brown, semi-transparent with darker veins. The second wings are well developed; in the majority of the imagines examined they are twice as long as the tegmina, forming so-called "cauda". The tegmina in the males have the typical venation: the stridens area with two oblique veins, the mirror with one vein (Fig. 3). 
The genital organs of the male (Figs $4 \mathrm{a}-\mathrm{c}$ ) are almost identical to those illustrated by MASSA et al. (2012, plate 81, fig. 9) and by BIRRER \& CORAY (2000), but are more strongly sclerotized. The spermatophore is pear-shaped (Fig. 4d). The ovipositor is a little longer than the hind femur, slightly bent upwards with a flattened, enlarged and sharply-pointed terminal part which makes up about one fifth of the whole length. The cerci are nearly as long as the ovipositor, with short thick and very long hairs.

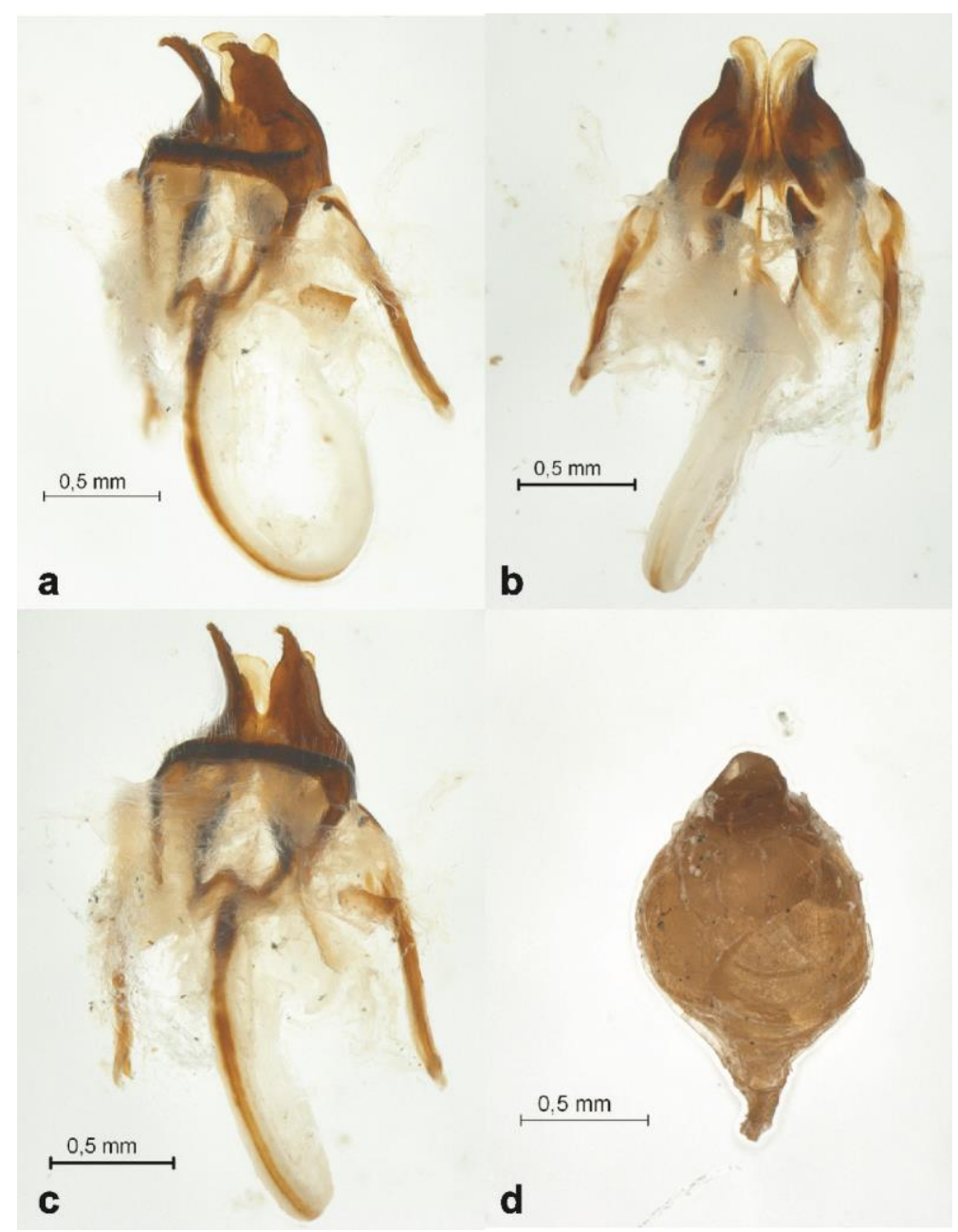

Fig. 4. Eumodicogryllus bordigalensis, genital organs of male (Sobibór): a - lateral view; $\mathrm{b}$ - ventral view; c - dorsal view; $d$ - spermatophore. 


\section{DISCUSSION}

All the indigenous specimens of $E$. bordigalensis are long-winged and all came to light; it seems, therefore, that they were migrating. The positions of the Polish localities suggest the likely direction of migration - from the south and south-east (Fig. 1). However, the great majority of foreign adult individuals of this species in our collection are also macropterous. In the light of these facts, it seems surprising that the southern cricket is still considered as flightless and its long-winged form as very rare. Most papers providing data on the morphological characteristics of E. bordigalensis omit the length of the second pair of wings but always state the dimensions of the tegmina. These comments apply both to earlier publications (BRUNNER V. WATTENWYL 1882, CHOPARD 1943, 1951, HARZ 1969) and to recent ones (MAAS et al. 2002, KoČÁREK et al. 2005, BELLMANN 2006, MASSA et al. 2012). Wings shorter than the tegmina and completely covered were considered normal, whereas wings longer than the tegmina were treated as very rare and unusual. If the second wings were not visible, they were assumed to be naturally shorter. The possibility of the secondary loss of wings by adult crickets was not usually considered. SELLIER (1954) was probably the first to notice the phenomenon of wing shedding in the southern cricket.

SELLIER (1954) was interested in wing polymorphism in crickets and studied the influence of internal (inheritance) and external (environmental) factors on the development of wings. Some European crickets always occur in the macropterous form (Gryllus bimaculatus DE GEER, 1773). In G. campestris, two forms are considered possible, but the macropterous one is very rare (only isolated cases are known). Pteronemobius heydeni (FISCHER, 1853) is usually known in the microptera form (wing atrophy) whereas the macropterous form is very rare. Melanogryllus desertus (PALLAS, 1771) is observed in natural habitats in three forms: macropterous - "deserta" ("caudalis") - as described by Pallas from Russia, brachypterous - "tristis" - described by Serville from Sardinia, and finally "melas" - described by Charpentier from Hungary. Eumodicogryllus bordigalensis also presents three forms: the typical bordigalensis, cerisyi with a second pair of long wings, and geminus with a slightly shortened tegmina with the second pair atrophied. SELLIER (1. c.) found that while intermediate forms were unknown in the previously mentioned species, all possible intermediate forms had been observed in the southern cricket.

In addition, SELLIER (1954) demonstrated that temperature had a significant effect on wing length only in the case of E. bordigalensis. When temperatures were relatively low and variable during postembryonic development, macropterous or parapterous adults were predominant, with the second pair of wings always being longer than the abdomen. When the crickets were grown at a constant, high temperature, there were more brachypterous specimens, but macropteric ones were still more numerous. Over many years of 
experiments with the crossbreeding of selected specimens, SELLIER (1954) came to the conclusion that the effect of heredity in individuals from brachypterous pairs was eliminated by the effect of low and changing temperature. The ability to shed wings some time after the last moult can produce the impression of brachypterism. This ability was later confirmed in E. bordigalensis by some other entomologists, e.g. INGRISCH (1978).

The observations of SELLIER (1954) regarding the wing polymorphism of $E$. bordigalensis have waited a long time for confirmation. This has probably been due to the difficulties in obtaining sufficiently abundant material. When, at the end of the 1990s, a new locality was found near Basel in northern Switzerland, entomologists were able to obtain only single specimens, even though, based on "singing", the cricket was very numerous there. BIRRER \& CORAY (2000) made a detailed description of its morphology, which indicated that, unlike Acheta domesticus, it had no second pair of wings. Two years later CORAY (2002) presented the results of breeding of the southern cricket. All the adult individuals, in several successive generations from the couple collected at the locality near Basel, were initially macropterous. Soon after the imaginal moult, the crickets displayed a kind of excitement and made rapid movements of the second wing, even though they were unable to leave the cage. After a period of 3-5 weeks the majority of them shed the second pair of wings, in this way becoming flightless, like the parental couple. At the same time, however, one cannot say with any certainty whether both the observations of SELLIER (1954) and those of CORAY (2002) made in an artificial culture are applicable to natural conditions. CHLÁDEK (1973) found a long-winged male in the Pavlovske Kopce (southern Moravia in the Czech Republic). HoLUŠA et al. (2007) subsequently confirmed the occurrence of these crickets near CHLÁDEK's location at the Novosedly railway station. Among the seven specimens collected, one male had only one long second wing, the other one had been shed. The remaining specimens were probably brachypterous or had already shed their second wings (missing information).

The occurrence of macropterous forms in natural environments has been insufficiently examined. These forms are considered very rare. In the past, many authors ignored the length of second wings as an inessential feature. Meanwhile, in the opinion of GOROCHOV \& LLORENTE (2001), it is the brachypterous form that is in reality very rare - the conviction regarding its dominance results from the secondary loss of wings. Histolysis of wing muscles is a probable consequence of the shedding of wings and egg production advances as a result of this release of energy reserves. Such a phenomenon in some other crickets, e.g. Velarifictorus parvus (CHOPARD, 1928) or Modicogryllus confirmatus (WALKER, 1859) was discussed by TANAKA (1991) and SUZUKI \& TANAKA (1998).

The clear predominance of macropterous specimens in our collection seems to confirm the opinion of GOROCHOV \& LLORENTE (2001). In Poland this cricket has been sporadically observed over the last 60 years, but no durable population has ever been discovered. All the 
specimens collected in Poland belong to the long-winged form and were caught when they were attracted to light. The find at Sobibór, where 15 macropterous crickets were attracted by light over a few successive nights, was remarkable. At least one male among them was capable of reproduction, as indicated by the spermatophore protruding from its abdomen.

When the southern cricket was recorded in new locations in Germany, Switzerland and Austria, the possibility that this species might be moving along railway tracks, was pointed out. The presence of about 100 singing southern cricket males was noticed in 1998 and 1999 at the railway station in Basel (Switzerland) (BIRRER \& CORAY 2000). This locality had probably not existed before 1995. Eumodicogryllus bordigalensis was recorded in 1995 in similar surroundings in southern Germany (ELST \& SCHULTE 1995). BOUWMAN (2010) found a small population of E. bordigalensis at a railway station in Ede (Netherland) probably the most northern locality in Europe. This author suggests that the southern cricket might have arrived there in a train from Mannheim or even Basel, where "good" populations of the species existed in a similar artificial habitat.

The circumstances in which crickets were caught at Sobibór, as well as the macropterism of all southern crickets collected there, suggest that they were migrants. One can probably assume the same for the single females from Krynica and Krzyżanowice. The arrival of these specimens to the light may be an accidental epilogue of the fly known as the "nuptial fly" among many insects. Nothing is known about such flying as the migration abilities of E. bordigalensis have never been studied.

\section{ACKNOWLEDGEMENTS}

We are very grateful to Prof. Dr. Marek Wanat (University of Wrocław) and to Dr. Eng. Marian ŁUSZCZAK (Krynica Górska) for donating their specimens to our research. We would like to thank the anonymous reviewers for their helpful and constructive comments.

\section{REFERENCES}

Bazyluk W., Liana A. 2000. Orthopterans Orthoptera. Catalogus faunae Poloniae. XVII, 2. Muzeum i Instytut Zoologii Polskiej Akademii Nauk, Warszawa. (in Polish)

BERG H.-M., ZunA-KRATKY Th. 1997. Rote Liste ausgewählter Tiergruppen Niederösterreichs Heuschrecken und Fangschrecken (Insecta: Saltatoria, Mantodea). 1 Fassung 1995. NÖ Landesregierung, Abteilung Naturschutz, Wien.

Bellmann H. 2006. Der Kosmos Heuschreckenführer. Kosmos, Stuttgart. 
BIRRER S., CORAY A. 2000. Eine neue Grille für die Nordschweiz: Eumodicogryllus bordigalensis (LATREILle, [1804]) (Orthoptera: Gryllidae). Mitteilungen der Entomologischen Gesellschaft Basel, 50 (2): 74-88.

Bouwman J.H. 2010. The bordeaux cricket Eumodicogryllus bordigalensis new to the Netherlands (Orthoptera: Gryllidae). Nederlandse Faunistische Medelingen, 34: 11-16. (in Dutch)

BRUNNER VON WATTENWYL C. 1882. Prodromus der Europäischen Orthopteren. Wilhelm ENGELMANN, Leipzig.

CHLÁdeK F. 1973. Weitere Funde der makropteren Formen von Geradflügler in der CSSR (Orthoptera, Saltatoria). Zprávy Československé Společnosti Entomologické při ČSAV, 9: 81-84. (in Czech)

ChOPARD L. 1943. Orthoptèrö̈des de l'Afrique du Nord. Faune de l'Empire Français I. Larose, Paris.

ChOPARD L. 1951. Orthoptéroïdes. Faune de France 56. Lechevalier, Paris.

CORAY A. 2002. Zur Makropterie bei Eumodicogryllus bordigalensis (LATREILLE, [1804]) (Ensifera: Gryllidae). Articulata, 17: 13-18.

CoRAy A., LeHMAnN A.W. 1998. Taxonomie der Heuschrecken Deutschlands (Orthoptera): formale Aspekte der wissenschaftlichen Namen. Articulata, 7: 63-152.

Elst A. V., Schulte T. 1995. Freilandfunde der Südlichen Grille, Tartarogryllus burdigalensis (LATR., 1804) und der „Exotischen Grille”, Gryllodes sigillatus (WALK., 1869) (Orthoptera: Gryllidae) im südlichen Rheinland-Pfalz. Articulata, 10: 185-191.

Gorochov A.V. 1986. New and little-known crickets (Orthoptera, Grylloidea) from Middle Asia and adjacent territories. Trudy Zoologičeskogo Instituta SSSR, 140: 3-15. (in Russian)

Gorochov A.V., Llorente V. 2001. Estudio taxonómico preliminar de los Grylloidea de España (Insecta, Orthoptera). Graelisia, 57 (2): 95-139.

HARZ K. 1969. Die Orthopteren Europa, The Orthoptera of Europe I. Dr W. Junk Publishers, Hague - Boston - London.

Herrera L. 1982. Catalogue of the Orthoptera of Spain. Catálogo de los Ortópteros de España. Series Entomologica, 22. Dr W. Junk Publishers, Hague - Boston - London.

HoluŠA J., KoČÁReK P., VlK R., MARHOUl P. 2007. Southern Cricket Eumodicogryllus bordigalensis (Orthoptera: Gryllidae) in the Czech Republic: new records and notes on the biology and stridulation. Polskie Pismo Entomologiczne, 76 (1): 47-55.

INGRISCH S. 1978. Zur Autotomie der Hinterflügel bei Grillen. Entomologische Zeitschrift, 88 (1/2): $1-6$.

Kostrowicki A.S. 1953. A glance at the fauna of the planned reserve in Krzyżanowice on the River Nida. Chrońmy Przyrodę Ojczystą, 9 (5): 13-18. (in Polish)

KoČÁReK P., HoluŠA J., VidličKa L. 2005. Blattaria, Mantodea, Orthoptera \& Dermaptera of the Czech and Slovak Republics. Kabourek, Zlin.

LATREILle P.A. 1804. Histoire naturelle, générale et particulière des Crustacés et des Insectes XII. Dufart, Paris.

LianA A. 1975. Grillen (Orthoptera, Grylloidea) Polens. Fragmenta Faunistica, 20 (12): 179-210. (in Polish) 
MaAs S., Detzel P., Staudt A. 2002. Gefährdungsanalyse der Heuschrecken Deutschlands. Verbreitungsatlas, Gefährdungseinstufung und Schutzkonzepte. Bundesamt für Naturschutz, Bonn - Bad Godesberg.

Massa B., Fontana P., Buzzetti F., Kleukers R., Ode B. 2012. Orthoptera. Fauna d'Italia. Caldrini, Milano.

Olmo-Vidal J.M. 2006. Atlas de los ortópteros de Cataluña y libro rojo 2006. Generalitat de Catalunya. Barcelona. (in Catalan)

SELLIER A. 1954. Recherches sur la morphogenèse et le polymorphisme alaires chez les Orthoptères Gryllides. Annales des Sciences Naturelles (Zoologie), 11 série, 16: 595-739.

Storozhenko S.J., Gorochov A.V. 1992. Contribution to the knowledge of the Orthopteran fauna of Ukrainian Carpathians (Orthoptera). Folia Entomologica Hungarica, 52: 93-96.

SUZUKI Y., TANAKA S. 1998. Physiological trade-offs between reproduction, flight capability and longevity in a wing dimorphic cricket, Modicogryllus cofirmatus. Journal of Insect Physiology, 44 (2): 121-129.

TANAKA S. 1991. De-alation and its influences on egg production and flight muscles histolysis in a cricket (Velarifictorus parvus) that undergoes inter-reproductive migration. Journal of Insect Physiology, 37 (7): 517-523.

Thorens P., NAdig A. 1997. Atlas de distribution des Orthoptères de Suisse. Centre Suisse de Cartographie de la Faune, Neuchâtel.

VoIsin J.-F. 2003. Atlas des Orthoptères (Insecta: Orthoptera) et des Mantides (Insecta: Mantodea) de France. Patrimoines Naturels, Paris.

WiLLEMSE F. 1984. Catalogue of the Orthoptera of Greece. Fauna Graeciae 1. Hellenic Zoological Society, Athens.

Received: 2 January 2019

Accepted: 6 February 2019 